\section{7. 中枢血圧調節機構に関する研究}

一とくに睡眠と日内血圧変動との相関—— 太田繁興 山口明志 村山義治 清水 晃 佐々木彰 坂木洋一 沢田寿一 矢口 勇 海老原為博 大坪芳臣 天野長久 本多平吉 秋田泰正 神田修治 坂本利正 (昭和大学 成人病科)

本態性高血圧に対する中枢神経性機序, すなわち中枢 神経系の血圧变動の影響を検討する目的で睡眠深度と血 圧との関係について研究をかさねてきているが，今回さ らに, 睡眠が日内血圧変動に与える影響について検討を 加えた。

家兔に慢性電極を植えこみ，刺激を加えると視床下部 前部では, 刺激直後やや血圧は下降し, 視床下部後部, 海馬, 網様体では刺激後逆に血圧は上昇を示した。しか し断眠家鬼では刺激直後著明な血圧上昇を認め, とくに 網様体, 海馬, 視床下部後部において 40〜 50 $\mathrm{mmHg}$ の 血圧上昇を認めた。同時に直接刺激にて血圧上昇を認め なかった視床下部前部でも血圧上昇を示し，日内血圧変 動の著しいことを認めた．また演者らは睡眠を完全睡眠 型と不完全睡眠型に大別し，不完全睡眠型をさらに初 期熟眠型, 中期熟眠型, 後期熟眠型, 不全型とに分類し, これら各睡眠型と血圧, 脈波, 心電困, 眼球運動, 呼吸, GSR，脈拍との相関を睡眠から日内に拈けるおのおのの 変動を検討した結果，完全睡眠型では睡眠深度に一致し て血圧, 体温, 脈拍, 脈波は低下するが, GSR は増加 する. Paradoxical sleep の出現時には眼球運動の出現 と細かな血圧変動を認めるこのタイプの日内変動は比較 的安定した動きを示したが，不完全睡眠型では，血圧， 体温, 脈拍はともに睡眠深度に平行して低下する. しか し日内血圧の収縮期変動が目立つことと同時に拡張期血 圧上昇が持続する不安定な状態を認めた．以上のごとく 家兔の断眠による特殊条件下では中枢刺激に対する血圧 変動が著しく，なおかつ日内血圧変動が著明であること を認めた．完全睡眠型と不完全睡眠型とでは明らかに血 圧変動に相異が認められ，なおかつ自律神経系に関する 反応も異なってくることを認めた。これら睡眠が日内血 圧変動に重要な相関関係を示すことから中枢血圧調節機 構には覚醒と睡眠との間にはリズムがあり，これは血圧 に関する Homeostasis につながっているものと考える。

買問：吉田 稔（弘大 大池内科）我々は, 日内血
圧変動について検討した際に，高令者は若年者に比し， 高血圧者は正常血圧者に比し，さらに随意血圧で測定し た場合には準基礎血圧で測定した場合より日内血圧変動 が大きいという結果を得ておるが，先生のご発表の中で， 完全睡眠型，不完全睡眠型，各群において年令構成，高 血圧者の占める割合，血圧測定の条件などを考虑してい るかどうか．また，それを考慮した上でも，同様なこと がいえるかどうかご教示ください。

答：太田繁興 我々は年令的分類による日内血圧变動 の検討はせず睡眠状態が日内血圧変動が大きい事実を認 めている。 また拡張期，収縮期血圧による血圧の影響が 日内血圧変動に及ぼすかどうかについても，睡眠が不完 全であれば拡張期収縮期血圧変動が大であり日内血圧変 動も著しいことを認める。

\section{8. 血圧之 CMI 心满血管系自觉症状}

植松 稔 高橋 賛

(岩手医大 公衆衛生学)

昭和 44 年 10 月岩手県医師会の予防医学的活動の一 環として熳下いっせいに県民の血圧測定が行われ，私ど もは測定結果の集計解析を依頼された. 被検者総数は 10,178 人で男子 2,577 人，女子 7,421 人であった。 血圧の測定には水銀血圧計を用い，測定の前に被検者に 数回の深呼吸を行れせ，体位は椅坐位とし，右上腕を測 定部位とすることを原則とした，血圧測定に合わせて， 本人および世帯主の職業が大分類 11 のどれに該当する かを調べ，自覚症状として CMI，195 項目のうち C 項 の心臓血管系 12 項目について問診した。集計解析には 昭和 41 年国民栄養調査報告の資料を用い, 血圧の性・ 年令階級別平均值および標準偏差を用いて，各人の最高 血任を性，年龄に対応するプロビットに換算し解析し た.

血圧プロビット別 CMI C 項の訴え率で著明な項目が あまりみられない，したがって血圧と自覚症状とは関連 性があまり認められない。血圧の集団検診の場合には自 覚症状の有無にかか未らず血圧測定を行うべきであり， 昭和 42 年度の死因別死亡率で脳卒中は $25 \%$ を占めてお り，CMI で問診したことのうち血圧プロビットともっ とも関係のあるものは脳卒中に関する家族歴である，脳 卒中の予防を目的とした血圧管理においては，本人また は家族に高血圧の既往のあるものを high risk group と 
して平素から診療機関と密接な結びつきが行われれば, 脳卒中の発症をたとえなくすことはできないとしてもそ の時期をかなり遅らせたり，仮りに発症してもその予後 を十分良好ならしめる可能性がある。

\section{9. 老年者の血圧ならびに自觉症状よりみた疾患予後} 宮崎徳蔵 新 城之介 和田行一 赫 彰郎 岩崎一永積 惊 山野登史 橘 紀光 正田哲一 比企秀男 手塚博幸 幡生精一郎

（日医大 新内科）

宮崎 正 本間達志

（養育院付属診療所）

主として 60 才以上の東京都養育院の老年者 823 名に ついて，血圧ならびに自覚症状を調べ，その経過を 3 年 以上追跡した成績を報告する.疾患別発病数は，脳血栓 26 例, 脳出血 10 例, 5 血性心不全 13 例, 心筋硬 塞 2 例, 肺炎 5 例, 胃癌 5 例, 肺癌 3 例, 肝硬変症 1 例 である. 脳血栓 26 例について, 収縮期圧 $200 \mathrm{mmHg}$ 以上では, $3.2 \%$, 挔張期圧 $120 \mathrm{mmHg}$ 以上では, 7.7 $\%$, 脳出血 10 例について, 収縮期圧 $200 \mathrm{mmHg}$ 以上 では, $6.0 \%$ ，拡張期圧 $120 \mathrm{mmHg}$ 以上では， $2.6 \%$, 弓っ血性心不全 13 例について, 収縮期圧 $200 \mathrm{mmHg}$ 以上では， $2.4 \%$ ，拡張期圧 $90 \mathrm{mmHg}$ 以上では, 2.8 $\%$ と血圧上昇に伴い，脳血管障害の頻度が高く，心疾患 がこれに次ぐ. しかも, 脳卒中患者の自覚症状として, めまい, 頭痛, 耳鳴りのいずれかを訴光，収縮期圧 200 $\mathrm{mmHg}$ 以上では, $5.5 \%$, 拡張期圧 $120 \mathrm{mmHg}$ 以上で は，14.8\%，手足のしびれまたは舌のもつれを訴えた ものは, 収縮期压 $200 \mathrm{mmHg}$ 以上では, $22.2 \%$, 掂張 期圧 $120 \mathrm{mmHg}$ 以上では，30\% と頻度が高く, 自覚症 状のない 249 例中からの脳卒中発生は 3 例にすぎなかっ た。また うっ血性心不全患者では, 動悸, 息切れ, 胸部 圧迫感のいずれかを訴光たものは，縮収期圧 $200 \mathrm{mmHg}$ 以上では, $13.3 \%$, 拡張期圧 $90 \mathrm{mmHg}$ 以上では, 13.2 $\%$. 下腿浮腫について, 収縮期圧 $200 \mathrm{mmHg}$ 以上では, $33.3 \%$, 㧒張期压 $90 \mathrm{mmHg}$ 以上のものでは, $26.1 \%$ と高くなつている. 夜間尿回数では, 2 回以上のものに 脳卒中またはうっ血性心不全の発生頻度が高い.

算問：前田如矢（阪市大 第 1 内科） 1) 万っ血性 心不全の発生をみたものがかなりあり, しかも比較的早 期の.出現が認められる. 臨床的背景になんらかの心障害 を示唆する因子（たと党ば ECG 異常，心拡大など）の ある症例からの発生が多かったか。
8 巻 4 号 $(1971: 7)$

2）脳卒中を出血と血栓に clear cut に分類されてい るが，その区別はどのようなデータにもとづいてなされ たか.

答：宮崎徳蔵 1）弓っ血性心不全患者，その他全症 例について，心電図，胸部 $\mathrm{X}$ 線検査なぞを施行している が，今回は血圧，自覚症状の面よりみた一定期間内のこ れら疾患の発生のみについて検討した。

2）脳血栓，脳出血の鑑別診断については文部省の脳 卒中診断規準に從い，全例に腰椎穿刺を行い，死亡した 例には, 剖検により確認した。

\section{0. 高血圧患者の臨床的背景因子の意義}

—とくに 5 年間に打ける重症度および降圧効 果の推移とその予後についてー— 前田如矢 谷 勲 塩田憲三 （大阪市大 第 1 内科）

高血圧症の治療経過および予後を左右する因子として 諸藏器の血管性病変に由来する合併症, とりわ悩, 心, 腎の変化が重視されている.

今回, 当教室入院扣よび外来の高血圧患者のうち， 5 年間臨床経過を追求しえたものおよびその予後を確認で きた 68 例を対象とし, 症例の重症度，降圧効果などの 推移拉よびその予後について検討し，次のごとき結果を 得た。なお症例は当教室試案の重症度分類に従い，I (mild), II (moderate), III (advanced), IV (far advanced）の 4 群に分かった.

1）重症度の年次変化: 各群とも年数とともにより重 症となる例が漸増し，II 以上にこの傾向著明，年令別に は 40 才代以下の若年例では重症度は観察期間中不变の ものが多く, 50 才代以上では重症度の増加傾向が著明 となる.

2) 治療内容と重症度の推移：治療継続群のI 拈よで II はほとんど不変. IIII, IVでは重症度は年とともに増加 する．治療中断群では 4 群とも年とともに重症度は增加 し，継続群よりこの傾向は顕著である。

3) 降圧効果の推移： 5 年間の経過で重症度の増加す る例では降圧効果も平行して低下，とくに拡張期圧での 降圧が得がたくなる.

4) 予後：心・脳合併症の発生率扰上び死亡率ともに, 重症度と平行した関係がみられ重症例ほど高くなり，か つ治療中断群に著明である. 年令との関係では 50 才以 降とくに 70 才以上の例に不良である.

以上の成績より高血圧症の治療, 予後などに臨床的背 
一 般

景因子が重要な役割を演じて拈り，これらを総合的にな がめた教公試案の重症度分類の意義が再確認された。

\section{1. 本態性高血圧症における長期食塩制限の影響}

I ）血獎 Renin, 血獎 Angiotensinase 活性の变動 藤瀬幸保 宮原光夫 飯村 攻 星川弘紀 （札医大 第 2 内科）

本態性高血圧症患者に食塩制限をすると血圧が低下す ることは既知の事実である。我々は本症患者に 1 日 $3 \mathrm{~g}$ 以下の食塩制限食を 4 週間投与し，その間の血圧，血獎 Renin 活性 (PRA), 血獎 Angiotensinase (ATase) 活 性を経時的に測定し，血圧低下との関連について検索し た。

対象・方法：当科入院の本態性高血 圧症 患者 15 例 （男 8 例・女 7 例）年令 $20 \sim 69$ 才（平均 49 才）を対 象とし PRA は Helmer 法の金子氏変法, ATase 活 性は Hypertensin Ciba を基質とし pH 7.2, $37^{\circ} \mathrm{C} て ゙$ incubate し bioassay にて测定した.

結果：食塩制限により 全例に明らかな降圧を認め, $\mathrm{P}$ RAは対照期平均 $2.9 \mathrm{ng} / \mathrm{ml}$ に比し減塩 1 週平均 $9.8 \mu \mathrm{g}$ $/ \mathrm{m} l(p<0.001) ， 4$ 週 $11.0 \mathrm{ng} / \mathrm{ml}(p<0.001)$ と有意に増 加する. 食塩制限による血圧低下と PRA 増加との間に は負の相関傾向が認められる. しかし普通食䬣に拈ける 本症の血圧自然動摇と PRA の間には一定の傾向はない. ATase 活性は食塩制限により平均 $45.7 \%$ から 1 週目 $48.6 \%(p=0.05) ， 4$ 週目 $48.8 \%$ と上昇する。また食 塩制限 1 週では血圧降下度との間に負の相関傾向が認め られる。また PRA 活性上昇值と ATase 活性上昇值 の間には有意の相関は認められない，以上より本症にお ける食塩制限時の PRA の上昇は単に降圧による effective renal blood flow の低下によるとは考えがたい. また ATase 活性上昇は一義的なものでなく ReninAngiotensin 系の増加に適応するなんらかの機序にもと づくものと考えられる.このATase 活性の上昇は間接 的にしろ本症の血圧調節の一因子としての意義は有しよ 5. 食塩制限時の降圧機序に Renin-Angiotensin 系の 面から考察を加えた。
演

題

$8: 179$

\section{2. 本態性离血圧症における長期食塩制限の影蚃}

II) 水・電解質代謝面より

藤瀬幸保 宮原光夫 飯村 攻 千田昭宏 （札医大 第 2 内科）

本態性高血圧症患者に長期食塩制限（1 日 $3 \mathrm{~g}$ 以下， 4 週間) を施行し, その間の血圧, 血漿 Renin 活性 (P RA), Renal Plasma Flow (PRF), Glomerular Filtration Rate (GFR), Renal Blood Flow (RBF), Hematocrit $(\mathrm{Ht})$ ，血墏 Osmorality, Plasma Volume を経時的 に観察した。

対象・方法: 対象は演題 91 に準ずる. PRA は Helmer 法の金子氏変法, 腎 Clearance は, Paraaminohippuricacid; Thiosulfate による標準法, Osmoraiity は Osmett-Osmometer により測定した.

結果：食塩制限により全例血圧は低下する. 食塩制限 時血清 $\mathrm{Na}$ は不変であるが，尿中 $\mathrm{Na}$ 排泄量は $1.5 \mathrm{~g}$ 以下と著减する。この尿中 $\mathrm{Na}$ 減少と PRA 上昇とは 食塩制限 1 週で逆相関 $(p<0.05)$ を認める. 一方 Osmorality, $\mathrm{Ht}$ は前平均 $(282 \mathrm{~m} \mathrm{Osm}, 42.1 \%$ ) から 1 週目 平均 $(277 \mathrm{~m} \mathrm{Osm}, 41.8 \%), 4$ 週目平均 (274 m Osm, $40.2 \%$ ) と低下傾向を示す. また RPF RBF GFR は前 平均 $(575 \mathrm{ml} / \mathrm{min}, 998 \mathrm{ml} / \mathrm{min}, 127 \mathrm{ml} / \mathrm{min})$ から 1 週 目平均 $(559 \mathrm{ml} / \mathrm{min}, 968 \mathrm{ml} / \mathrm{min}, 112 \mathrm{ml} / \mathrm{min}), 4$ 週目 平均 $(517 \mathrm{ml} / \mathrm{min}, 868 \mathrm{ml} / \mathrm{min}, 118 \mathrm{ml} / \mathrm{min})$ といずれ も 4 週目に低下する傾向がある. しかし Plasma Volume には一定傾向はない. また GFR の変化はPRA 変 化と負の相関 $(p<0.01)$ を示す. 以上より本症患者の食 塩制限時 PRA 上昇は単なる RBF の低下によるものと は考えがたく，他方尿中 $\mathrm{Na}$ 排泄量減少と PRA 上昇 が負の相関を示すことから Na 摂取量の減少に伴う Na 沪過量の減少と, GFR の低下などょり Macula densa 部の $\mathrm{Na}$ 含有量が減少し Renin 分泌が増強されるもの と思われる. しかし本症における食塩制限が降圧をもた らす機序についての解明は困難であり今後一層検索を進 めたい.

93. 本態性高血圧症における長期食塩制限の影響 III）血行動態の変動

相馬公夫 宮原光夫 菊入 剛 阿部久雄

県 賢 高橋尙志 西根 司 （札医大 第 2 内科）

食塩制限による降圧の機序解明を目的に，長期食塩制 限下の心血行動態 (RISA による体外計測法)，指尖血 
$8: 180$

行動態 (plethysmograph 法) の変化を検索した。当科 に入院せる本態性高血圧患者で, 食塩制限 (1 日 $\mathrm{NaCl}$ 量 $3.0 \mathrm{~g}$ 以内) 4 週間を維持, 開始後 1 週内に 1 日尿中 Natrium 排泄值 $1.5 \mathrm{~g}$ 以下，かつそれを維持せる症例 10 例を対象とした。食塩制限により全例で血圧は下降 し，これに伴い全末梢抵抗，指尖血管抵抗の低下をみる も, 心拍出量, 指尖血流量には著変ない. Hexamethonium $(0.3 \mathrm{mg} / \mathrm{kg}$ 筋注), ならびに Angiotensin (0.015 $\mu \mathrm{g} / \mathrm{kg} / \mathrm{min})$ 持続静注に対する反応性には有意な变化を 認めないが, Noradrenaline $(0.3 \mu \mathrm{g} / \mathrm{kg} / \mathrm{min})$ 持続静注に 対する反応性は平均血圧，全末梢抵抗でみると有意差は ないが減少傾向をみた. 食塩制限による血漿 Renin (P RA) 活性の変動と Noradrenaline, Angiotensin 反応性 における変化をみると, 前者ではPRA 活性の上昇に伴 い前腕平均血圧，指尖平均血圧ならびに指尖血管抵抗で みた反応性は上昇傾向がみられる．また後者では有意な 相関ではないが PRA 活性の上昇に伴い末梢血管の昇圧 反応性の低下傾向がみられる．以上の成績より降圧の機 序につき若干の考察を加えた。

算問：柴田宣彦（大阪府立成人病七ンター） Na 制 限が Noradrenalin, Angiotensin の感受性の低下をきた すことはよくわかったが，この機序はいかようなもので あるか敃えください. 私どもは先に動脈収 縮性 蛋白 の ATP による収縮活性は反応液中の $\mathrm{Na} / \mathrm{K}$ の増大に より増すことを報告したが，食餌中 $\mathrm{Na}$ 制限は，動脈壁 $\left(\mathrm{Na}^{+}\right)$の低下をきたしているかどうかもし検討してお れば合わせてお教えください。

答：相馬公夫 1) Angiotensin に関しては一部に Kaplan の仮説もあるが, 現時点で私どもの研究では不 明である.

2) Noradrenaline 反応性に関してもAngiotensin 同 様不明である。

\section{4. 䯩血圧症における種々降圧郕の循環動態に及ほす 影響について}

舟津敏朗 竹内伸夫 金 武雄 小野江為久 土屋雅之 平丸義武 竹越 袈 村上暎二 村上元孝 (金沢大 村上内科)

種々降圧剂の降圧機序を観察するため降圧剂投与前後 にお忷る循環動態变化を比較検討.

対象：高血圧を有する入院拉よび外来患者. 計 85 名. 方法 : ICG による dye-dilution method により心拍出
8 巻 4 号 $(1971: 7)$

量を測定し各種循環動態因子を算出した。結果 : 各種降 圧剂投与で血圧下降のあった例を集計して，次の結果を 得た.

Hydroflumethiazide $50 \mathrm{mg}$ 静脈内投与一血圧下降が少 なく, 諸種循環動態因子に一定の変化傾向はみなかった。 Trichlormethiazide 4〜8 mg または Methychlothiazide 2.5〜 $5 \mathrm{mg}$ を 1 12 週経口投与一全末梢血管抵抗 (TP R) の減少傾向，循環時間の遅延のみでほかの日子に一 定の変化をみなかった，投与期間を考慮すると，投与後 早期に心拍出量 (CO) 増加, TPR 減少. 次いで CO 減 少, TPR 増加と変動するように思われた。 Reserpine $1 \mathrm{mg}$ 静脈内投与一心拍数 $(\mathrm{HR})$ 減少 $(p<0.02) \mathrm{TPR}$, $\mathrm{CO}$ 減少傾向. Reserpine $1 \sim 2 \mathrm{mg}$ または Methoxydeserpidine 30〜60 mg 経口投与一変動は一定でなく傾 向はつかめなかった. Hydralazine 10〜20mg 静脈内投 与一HR 増加 $(p<0.01) \mathrm{CO}$ 減少傾向 $\mathrm{SV}$ 減少 $(p<$ 0.02) TPR 増加 $(p<0.02)$. Hydralazine $60 \mathrm{mg}$ 経口 投与一 HR 減少 $(p<0.05)$ TPR 減少. $a$-Methyl-dopa $750 \sim 1,500 \mathrm{mg}$ 経口投与-CO 増加 $(p<0.02) \mathrm{TPR}$ 減 少傾向.

Propranolol $5 \mathrm{mg}$ 静脈内投与一 $\mathrm{CO}, \mathrm{SV}$ ならびに $\mathrm{T}$ $\mathrm{PR}$ 減少 $(p<0.02, p<0.05, p<0.05) \mathrm{HR}$ 減少傾向.

Propranolol 30〜60 mg 経口投与一HR ならびに CO 減少 $(p<0.02, p<0.05) \mathrm{TPR}$ 増加 $(p<0.02)$. 以上 各種降圧剂は投与方法ならびに期間によりその循環動態 への影響は種々であり，降圧剂投与に当っての循環動態 の測定はその適応決定に意義あるものと考えた.

犋問：関 一郎（阪医大 第 1 内科） Per oral で日 を変えて計測した場合の自然変動は何\%くらいになるも のか.したがって何\%以上の変化によって薬剤による有 意な変化と考えてよいかご教示ください.

留問：梶原長雄（駿河台日大病院 循環器科）各種 降圧剂の腎流血量, 冠血流量に及ぼす影響を検討してい たらご教示いただきたい。もし聞きもらしていたら括許 しください.

答：竹越 襄 1) Per oS，と intravenously の投与 はそれぞれ別個の対象を選んである.

2）安静臥床後 10 分以上血圧ならびに脈拍の安定を みたのち測定している，とくに血圧の自然経過と循環動 態の変動に関しては検討していない。 


\section{一 般 \\ 95. 高血圧症の研究 \\ 演 \\ 題 \\ $8: 181$ \\ Phentolamine によるI-E 間隔の短縮についても， $\alpha$ - Blocking により $\beta$-優位の状態になったのか，あるいは 末梢抵抗低下に対する代償作用によるものかについての 議論も speculation にもとづいている.}

$-\alpha$-Stimulant， $\alpha$-Blocker に上る心周期各時相の変 動について一

竹内伸夫 舟津敏朗 金 武雄 土屋雅之

小野江為久 竹越 襄 村上暎二 村上元孝

$<$ 第 2 内科 $>$

平丸義武＜公衆衛生>

（金沢大）

高血圧症の成因に括计る自律神経系の関与を究明する ために心尖拍動波による心周期時相分析という面から高 血圧者における $\alpha$-Stimulant および $\alpha$-Blocker に対す る反応を正常血圧者と対比检討し，次の結果を得心。

1) Noradrenalin 負荷に対する反応は正常血圧者, 高血圧者で差はなく, 両群とも $\mathrm{R}-\mathrm{R}$ 間隔, Q-II 間隔, E-II 間隔（駆出時間）は延長し， Q-E 間隔（緊張時 間）は短縮した。したがって E-II/Q-E（血行動態比） は增加した。

2) Phentolamine 負荷に対する反応は両群とも R-R 間哣，Q-II 間隔，Q-E 間隔， I-E 間隔， E-II 間隔 は短縮しているが $\mathrm{R}-\mathrm{R}$ 間隔の短縮は高血圧者でやや少 なく, 逆に E-II 間隔の短縮は高血圧者で多い傾向を認 めた。

II -O 間隔（等容弛緩期）は両群とも延長し差は認め られない，E-II/Q-E は正常血圧者で増加するのに反し て高血圧者では減少した。

3）上記のごとき心周期各時相の変動は $\alpha$-Stimulant, 扰よび $\alpha$-Blocker に対する末梢血管抵抗の変動に伴 弓 心筋の代償作用を反映するものと考兄られるが，かかる 二次的反応から高血圧者では $\alpha$-Stimulant に対する sensitivity は正常血圧者に比しほとんど差はないが， $\alpha-$ Blocker に対する sensitivity がやや弱いように思われる。

質問：上羽康之（神戸大 第 1 内科） $\alpha$-Stimulant および $\alpha$-Blocker 使用時の心機能の变化における薬物 自体の作用以外，代償的 $\beta$ 刺激あるいは反応的迷走神経 興奮などの諸因子の分析的評価はいかがか.

答: 竹内伸夫 我々の研究成績は心周期各時相の変動 からの結論を示したものであり，ほかの循環機能に関す る data にはもとづいていない。

したがって，Noradrenalin によるIE 間隔の短縮は 心筋传対する直接作用か, 末梢血管抵抗増加に対する代 償作用か，両方とも考兄られるがこれは speculation に よる結論でありいずれによるかは，ほかの data にもと づいているのではない.

\section{6. $\beta$ 遮断剤の高血圧に対する影響}

山上 徹 柴田宜彦 森岡豊嗣 宮川定吉 戸山靖一 (大阪成人病センター)

$\beta$ 遮断剂の作用機序として, 従来よりの $\beta$ receptor 遮断以外收縮蛋白，とくに動脈壁収縮蛋白自体一の作 用に言及した成績がみられる，その観点よりすれば， $\beta$ 遮断剤により細動脈の拡張をきたし，血圧の降下が期待 できる，そこで，本態性高血圧症 47 例，その他の高血 圧 7 例, 計 54 例に Propranolol 1 日量 $60 \mathrm{mg}$ を経口 投与し，血圧値の変化を検討した。

対象の性別は男性 27 例, 平均年令 51 才, 女性 27 例, 平均年令 56 才である.

Propranolol 使用前の血圧值の平均は，収縮期圧 175 $\mathrm{mmHg}$ 㧒張期圧 $99 \mathrm{mmHg}$ であり, Propranolol 使用 2 週後には, 収縮期圧 $155 \mathrm{mmHg}$, 拡張期圧 $91 \mathrm{~mm}$ $\mathrm{Hg}$ であった。

個々の症例について検討すると約 43\% に著効，35\%

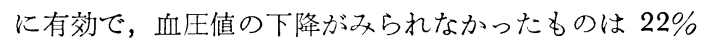
であった。

心電龱における冠硬化症の有無, Propranolol の negative chronotropic action と降压効果との間にはなん ら関係がなかった。

対象例の内，約 10 例について心音図，および，指尖 容積脈波の検討を行った。 心音図 Q-I 時間はほとんど 全例が延長し，脈波の弹性率は大部分が低下した。した がって, Propranolol $の$ negative inotropic action to よび細動脈の弾力性の増加は，ほとんぞ全例に認められ たが，降圧作用との間には関係がみられなかった。

以上の成績より，Propranolol には心収縮力を低下さ せるとともに細動脈の弾力性を增す作用があると思われ る. 一方，降压作用をも有すると考えられる。しかし， 降圧作用と，心収縮力低下，岗るいは血管㹡張作用との 間には密接な関係がみられなかった。

㬴問：村上暎二（金沢大 第 2 内科）94 席で発表し たごとく, 我々も Propranolol の降圧効果は, やや心 瀻に対する negative inotropic action が 1 次的かつ主要 なものと考劣ているが，先生はどう思われるか． 
留問：竹越 䘫（金沢大学）若年性高血圧症の投与 法ならびに投与期間に慣れの問題といかなる関連が認め られるか。

答：山上 徹 1) 臨床例におけるプロプラノロール の降圧効果の発現は, 基礎疾患の種類, 使用前の血行動態 の異常などにより变動するのは当然であるが，いままで のところ，ぞのような症例に效果的であるかどうかにつ いては一定の傾向は認められなかった。また，継続使用 による慣れの点についても一定の傾向はみられなかった。

2）プロプラノロールの降圧作用として,心蔵の negative inotropic action によることも十分考慮すべきで ある. しかし，動脈壁収縮蛋白に対する直接作用，指尖 容積脈波からみた動脈弾性率の変化などからみて, 細動 脈自体に対する影響も考慮してよいのではなかろうか。

\section{7. 老年者高血圧の血行動態}

— $\beta$-Blockade 負荷前後の心機能—— 有田頙二 守一雄 柏木政伸 進藤芳雄 臼井 孝 宮崎佳之 松井 豊 平山静栄 佐治金次郎 日险菊比児

（横浜市大 守内科）

60 才以上の動脈硬化性高血圧者（収縮期血圧 $160 \mathrm{~mm}$ $\mathrm{Hg}$ 以上, 拡張期血圧 $100 \mathrm{mmHg}$ 以下，心胸郭比 $50 \%$ 以下） 16 名, 本態性高血圧者（収縮期血圧 $160 \mathrm{mmHg}$ 以上，抎張期血圧 $100 \mathrm{mmHg}$ 以上，心胸郭比 $50 \%$ 以 上) 20 名に Propranolol $0.1 \mathrm{mg} / \mathrm{kg}$ を $1 \mathrm{mg} / \mathrm{min}$ の速 度で静注し, 10 分後における心機能を測定し負荷前と比 較検討した。

観察成績：1）平均血圧は動脈硬化性高血 圧症では $5 \mathrm{mmHg}$ の降下で変化率は $-4 \%$, 本態性高血圧症では ほとんど変化しなかった．2）心拍数は両者ともに約 18 $\%$ 減少した. 3) 心係数は動脈硬化性高血圧症ではほと んど変化なく，本態性高血压症では減少した４）全末 梢血管抵抗は負荷により動脈硬化性高血圧症ではほとん ど変化しないが，本態性高血圧症では著明に増大した (変化率＋20\%)，5）左心の仕事は両者で減少している. 6) 心収縮力 (心力係数) は負荷により動脈硬化性高血圧 症では増大をみたが, 本態性高血圧症ではほとんど变化 がなかった。

結語：収棭其血压の上昇を特徵とする動脈硬化性高血 圧症と本態性高血圧症の Propranolol 負荷による心血行 動態は明らかに差がある。

問：吉田 稔（弘大 大池内科）高血圧と動脈硬
8 巻 4 号 $(1971: 7)$

化との間には深い関連があると思われ，その因果関係に ついての報告もみられる。先生は, 本態性高血圧と動脈 硬化性高血圧を clear-cut に分類し血行動態を比較して いるが，この両疾患を独立疾患として分類できるものか どらか．また分類できるとすれば，動脈硬化性高血圧と 本態性高血圧との分類上の本質的な差異はなんなのか.

答：有田禎二 加令に伴い収縮期血圧のみ上昇するも の（動脈硬化性）と壮年期より収縮期および抎張期血圧 の上昇のあるもの（本態性）に分けた，後者には心拡大 がみられる．両者には発症上異なるものがあり予後，治 療法などが異なるものと考える。

\section{8. 老年者血圧症患者における心，監血行動態に関す 了研究}

中尾訓久 市来 修 太田 鉫 久下義文

(関西電力病院内科)

老年高血圧症患者に打ける心腎血行動態の変化を追求 するため，RI の二重標識法すなわち，131I-HSA と 125 I-Hippuran を同時に静注して，体外計測法により心放 射図とレノグラムを同時測定し，これを桑原，平川らの アナログ・シミュレーション法によって解析した。

対象は 40 60 才代の正常者 8 名と, 本態性高血圧 症および動脈硬化性高血圧症患者 56 名（40～ 50 才代 の壮年者群 26 名, 60 70 才代の老年者群 30 名) で, これを Scheie の分類による眼底所見にもとづいて Ho $\mathrm{S}_{0} \sim \mathrm{H}_{1} \mathrm{~S}_{1}$ の軽度群と $\mathrm{H}_{2} \mathrm{~S}_{2}$ 以上の 眼底变化の強い群と に分かった。

成績ならびに考案：体重当りの循環血液量は正常群に 比し，高血圧症群では減少の傾向を示したが，これは血 管壁のトーヌスの増加や動脈硬化などによる血管床の減 少に起因すると考兄られる。，心拍出量は高血圧群では減 少の傾向にあったが眼底变化の軽い40 才代の一部に正 常者を越えるものがあり，腎機能も克進していた。

左心系の平均循環時間は高血圧群では延長の傾向にあ りことに老年者群で著しく，これは心肥大，冠不全など の心電図变化とかなり符号する．体循環系の平均循環時 間は老年群および眼底変化の強い壮年群で延長し，体循 環系の血管抵抗の増大を示唆している．全身の平均循環 時留は老年群および眼底変化の強い壮年群で延長した。

RPF は，壮年者群で 眼底变化の軽いものの一部で正常 值を越え, 老年群の眼底变化の強いもので著しく低下 した.

心拍出量に対する RPF の比率および 125I-Hippuran 
の尿中排泄率も RPF とほぼ同じ傾庖を示した。

結語 : 壮年期の高血圧症ことにその初期の一部には RPF の堌加が心拍出量の増加をさらに上回っており， 正常者のそれを越えて，心拉よび腎機能の克進したもの があるのに対し，老年期の高血圧患者では，一般に心腎 機能は低下し，ことに眼底変化の強い群で心機能の低下 を上回る著しい腎機能の低下を認めた。

\section{9. 老年者高血圧症の循環動態}

リーホン・ユイング 寺沢富士夫

（浴風会病院 東大第 3 内科）

倉持衛夫 蔵本 築

（東大 第 3 内科）

血圧が収縮期 160 以上または拡張期 90 以上を示す降 生剂・利尿剂未使用の浴風会在園 60 才以上の老年高血 圧例のうち，心電図変化が軽微な範囲にとどまる 42 例

(男 14 例，女 28 例) について Evans blue による色 素稀釈法を用いて心拍出量を測定，循環動態の年令的推 移および血圧值との関係を検討した。

高血圧例では心係数は $3.24 l / \mathrm{min} \mathrm{M}^{2}$ で対照健常例 (20 例) の 3.75 に比し減少, 心拍数は増加し, 1 回拍 出係数は $45.4 \mathrm{ml} / \mathrm{M}^{2}$ と対照 55.5 に比し低下を認めた。 老年女子例での心係数は 60 才代, 70 才代, 80 才代之 加令で 3.44，3.20，3.11 ときわめて軽度の減少傾向で あったが，心拍数は増加し 1 回心拍出係数は 53.0 , $43.4,38.8$ と低下，60才代と $70 \cdot 80$ 才代とでは有意 の差であった.

老年者高血圧では加令とともに 1 回心拍出量が減少し 心拍数の増加で補償しているものと考えられる. 収縮期 血圧について 160 以下，160〜 180，180 以上の三群に 分けると，血圧の上昇で心係数は $3.53,3.48,2.89$ と 減少, 1 回心拍出係数も $50.2,44.4,39.7$ と減少した が, 拡張期血圧の上昇では両者とも減少傾向はみられな かった. 平均血圧 $100 \sim 110,110 \sim 120,120$ 以上の心 係数は $3.70,3.28,3.08$ で血圧の上昇とともに減少し た. 1 回心拍出係数も $51.5,43.9,40.5$ と減少し加令 とともに圧負荷に刘する心機能の低下が推定された。

Propranolol $0.1 \mathrm{mg} / \mathrm{kg}$ 静注負荷で心係数減少率 $-20 \%$ 以上を示すものは 75 才以上で 14 例中 10 例, 75 才 以下 21 例中 9 例であり，加令により交感神経系の機能 穴進が心機能賦活に関係している可能性が示唆された. 一方血圧の高低に関しては, Propranolol 負荷後の心係 数変化率は収繀期，昖張期，平均血圧いずれについても
著明な差がなく，圧負荷に対して交感神経機能六進状態 に差のないことが推定された.

筫問：吉田 稔（弘大 大池内科）我々は交感神経 機能をメコリールテストで検討してみると，加令ととも に $\mathrm{P}$ 型, すなわち sympathetic hyporeaetor の出現が 増加し，尿中排泄ノルアドレナリン量も減少している所 見を得ている. 先生は, Fropranolol 負荷による心係数, 一回拍出係数が 75 才以上では, それ以下に比し, その 減少率が大であることから, 交感神経機能の機能元進を 推定されておったが，心力あるいはその余力の低下など， 種々の因子によりこのような結果がでる可能性があると 思われる. Adrenergic nerve に依存性が高いというこ とと, adrenergic nerve の機能六進ということとは別の ように思われるがいかがか。

答 : 倉持衛夫 交感神経系の機能克進といういい方で はいろいろと複雑であろ 万が，75才以上で Propranolol 負荷後心係数変化率の大きいものが多いということは， 高令者で $\beta$ 受容体を介しての交感神経系の機能といらこ とで亢進ということを考えてよいと思う。

\section{0. 高令者にみられた褐色細胞腫の 2 剖検例}

家原利兼 井上 博 沢田 恂 古田睦広 三宅 儀 服部 譲 大谷芳武

（国立京都病院 内科）

我国における褐色細胞腫の報告例は 1960 年以来急速 に増加し, 1968 年吉植博士は 141 例の本邦例の統計的 調査を発表しているが，60 才以上のそれはほぼ 10 例く らいにすぎない. 我々は 60 才以上の高令者症例を経験 したので報告する.

症例 1 : 我々の共同発表者の一人古田が昭和 31 年に 経験したもので，80 才女子 2 度目の脳卒中発作に見舞 われ，死亡後解剖により偶然右副腎腫瘍（クローム親和 性）を発見されたもので，すでに発表されているので詳 細は省略する。

症例 $2: 65$ 才, 女子. 主訴はショック様の発作, 患 者は 20 才左眼失明 (原因不確) 45 才眼底出血, 63 才 時重悸, 口渇, 頭㾍, 高血圧をきたしていた。昨年 12 月末ごるりショック状発作, 以後漸次発作回数増 加し，激しい高血圧動摇をきたし，本年 3 月レギチンテ スト陽性, 尿蛋白糖陽性となり 5 月 1 日入院. 入院後悪 化度はなはだ速く，血圧は激しく動摇し糖尿を認め眼底 $\mathrm{KW}$ II b，薬斉にまったく反応せず，尿中カテコールア ミン上昇を示し 10 日目に大量下血を伴い死亡した。 


\section{$8: 184$}

日本老年医学会雑誌

解剖により左副腎腫瑒（クローム親和性）とともに右 腎門部に小腫瘤を認めた。前者は $5 \times 5 \times 670 \mathrm{~g}$, 後者 は $2 \mathrm{~cm}$ 直径であった. しかも後者もまったく同じクロ 一ム親和性を示している定型的褐色細胞腫であった。

経過がはなはだ速く手術しえず，かつまた部位診断も できえない症例であるが，右腎門部に左副腎とともに存 在したことははなはだまれな例であるので報告する。

101. 高血圧の発症における副腎の役割について 一一腎性昇圧因子の再検討第 4 報—— 山本 仁 吉良 潤 大西勝也 小西信哉 山取 要

（国立姫路病院 内科）

ウイスター系ラットを対象に Selye typc と Goldblatt type の高血圧を作った。これらの高血圧ラットに おいて, 副腎重量と心重量および血圧との間に相関を認 めた。ささらに，正常ラットに比べ，心・副腎重量とも増 加していた。

正常雄ラットで副腎摘出により，1\%食塩水投与にか かわらず，血圧は有意に低下した，雄ラットで左腎摘と 副腎摘出をした群と, 左腎摘のみした対照群に対して, 術後 3 日目より, 副腎摘出 6 日目のラットの酸処理腎工 キスを連続 10 日間 1 日 2 回 $1 \mathrm{cc}$ 朝夕皮下注射した。 対照群ではすべて血圧 200 以上呈したが，副腎摘出群で は，血圧は低下した。このタイプの高血圧には，副腎の 存在が必要のようである.

一方, Selye type の高血圧ラット 5 匹に, 術後 12 日 目に副腎摘出を行うと，無処置の対照群では高血圧は持 続したが，副腎摘出群では，血圧は全般に低下するもの の，1 匹は再び上昇したささらに Selye type の手術と 副腎摘出を同時に施行すると，生き残った 7 匹中 4 匹は 高血圧を呈した。 よって, Selye type の高血圧には副 腎が一見不必要なようである。しかし，この群では，副 腎摘出により副腎機能が完全に消失しにくい雌を使った 点や，副副腎の残存率の高い成熟ラットを使用した点問 題が残る．剖検時マクロで吟味したかぎり，副腎の残存 や再生はみられなかったが，組織学的に未検討なので, 副副腎の存在は否定でき奴。むしろ, Selye の手術と副 腎摘出を同時に行 $と$, 長期の $\mathrm{ACTH}$ 刺激により, 副 副腎がある程度副篮機能を補償した可能性がある。した がって，食塩を補償すれば副蜸機能が完全こなくても高 血圧が発生しうるとはいえぬ，急性実験で:，副腎が存
8 巻 4 号 $(1971: 7)$

在したほうが高血圧が発生しやすいとい方る。

問：金子 仁（東一病理）次の点について扣知ら せください，先生の実験は偏側腎について行ったものと 思らが.

1）腸間膜動脈に Periarteritis nodosa があったかど らか。

2)脳の病変はいかがか。

答：山本 亿 我々の急性高血圧実験で約 10 日目に 屠殺しており，腸間膜に著明な Polyarteritis nodosa 様 変化を認めていない，脳については調べていない，ただ し，著明な高血圧を呈したラットでは，マクロで心臟に 心筋梗塞様の白斑を認めている。組織学的検討について は次の循環期学会に報告する予定であるが，急性期の血 管障害は起こっている.

\section{2. 実験的高血圧症の病理学的研究（第 3 報）}

ラッテの高血圧症に対する唾液腺ホルモン (Parotin), ビタミン E 投与の影響につい $\tau-$

平田篤義 緒方知三郎 福士勝成
金子 仁 堤 晴朗 渡辺 靖
(日医大 老人病研)

目的：実験的高血圧症ラッテの脳ならびに血管系病变 を唾液腺ホルモン (Parotin)，および Vitamin E (VE) で抑制しうるや否を検討した。方法：本実験は第 10 , 第 11 回日本老年医学会総会の続報である. 今回はWis$\operatorname{tar}$ 系老ラッテ（生後 1 年 6 力月）雄淮各 75 匹を，(1) 過唾液腺症群 (Farotin $0.3 \mathrm{mg} / 100 \mathrm{~g} . \mathrm{wt} 1$ 日量として 週 2 回皮下注射)，(2) VE 投与群（VE一ユベラ末一10 $\mathrm{mg} / 100 \mathrm{~g}$. wt 1 日量経口投与), (3) 手術対照群（オリ エンタル固型飼料飼育）の 3 群に分かち, 各条件飼育 2 力月後に, 全群に対して Goldiblatt 変法 (同時両側腎動 脈狭窄術）を行い，術後 1 週後上り $1 \%$ 食塩水を飲用せ しめた，血圧は術前括よび術後 4 週， 7 週と計 3 回測定 し，術後 8 週後に屠殺し主として脳出血と腎および腸管 膜血管系病変を検索し比較考察した，血压 $160 \mathrm{mmHg}$ 以上で，しかも腎硬塞などの病变あるラッテのみを手術 効果 $(+)$ として検索対照とした。実験結果：一病理組織 学的所見一手術効柴 $(+)$ のラッテにみられる主所見は, 腸間膜の結節性動脈周囲炎 (PN) であるが, 各群別:腸 間膜 PN 発生率を比較すると, 雄雌ともに VE 投与群 （雌 3/11, 雄 3/9) が他群に比して少ない傾向にあり, Parotin 投与群 (雌 $5 / 12$, 雄 $1 / 3$ ) と手術対照群（雌 
一 般

3/6, 雄5/8) の間には差がみられなかった. PN 発生原 因はいまだ明らかではないが，動脈腔からその壁内への 血墏浸潤により動脈壁の Fibrinoid 変性を若起するもの と考兄られ，VE 群は PN 変化が少なかった。なお， 脳の出血性病変は各群にまったくみられなかった。結論 : 1) VE 投与群は雄雌々もに Parotin 投与群, 手術対 照群に比し, 腸間膜の結節性動脈周囲炎が比較的少ない 傾向にあった。 2) Parotin 投与群と手術対照群には大 差がなかった３）第 10 回本学会発表と同様, 3 群の 高血圧ラッテには脳の出血性病変はまったく発現しなか た.4）VE は血管透過性を阻止する働きがあると推察 される.

質問：小島原将保（群大 第 2病理） 1） 正常老ラ ットの腸間膜動脈には内膜細胞が存在したかぞうか.

2）内膜に類線維変性なしに動脈硬化性病変はみられ たかどうか.

答：金子 仁 1) 内膜細胞に関してはみていない。

2） Fibrinoid 変性のないもので内膜の肥厚した例は ない。

\section{3. 高血圧症の左房機能（第 1 報）}

一左房容積と右心機能を中心として一

金 武雄 舟津敏朗 竹内伸夫

小野江為久 土屋雅之 平丸義武

竹越 襄 村上暎二 村上元孝

（金沢大 第 2 内科）

我々は高血圧患者に心血管造影を使用して左房容積の 測定を行うと同時に，右心系との関係についても検討を 加えたので報告する.

対象は明らかな心不全を有しない高血圧者 14 例（男 11 例，女 3 例，平均年令 46.4 才）で正常血圧者 6 例 (男 4 例, 女 2 例, 平均年令 21.8 才) である.これら の患者に右心カテーテルを施行し, 心内圧の測定後, 心 血管造影を行い, Sauter らの方法にもとづいて, 左房 容積を測定した。 その結果, 高血圧者群の左房容積は明 らかに正常血圧者群に比して多い。しかし容積差はほと んどかわっていない，高血圧者群については，左房最大 容積は収縮期血圧で相関傾向を示すほか，加令とともに 容積の增加が認められるが，これは正常血圧者群では加 令と著明なる容積差がみられないとの報告から考古合わ せると興味深い。一方罹病年数とは相関傾向をみていな いが,これについては, 客観的に正確な䍜病年数が求め られないことによると考えられる。
演題

$8: 185$

左房最大容積と右心機能との関係では, 肺動脈楔入脈 圧は最大容積と相関傾向をもっている. そして肺動脈拡 張期压や右室拡張末期圧の軽度上昇, 右房圧の増大など が出現する。

すなわち対象に選ばれた症例にはうっ血性心不全など を有する重症例がないことから, 高血圧症の比較的早期 から血行動態的にも, 右心系への負荷が少なからず存在 することも示唆された.

\section{4. コロトコフ音出現時間の診断的価値の再検}

\section{討（第 2 報）}

- $\mathrm{Q}-\mathrm{K}$ 時間と大動脈弁口収縮期雑音— 吉武義之 橋田昌晴 湯浅和男 森和夫 土屋幸彦 鴫谷亮一

(群馬大 鴫谷内科)

ECG の Q よりコ音出現までを $\mathrm{Q}-\mathrm{K}$ 時間と呼び, Q-Ks (systolic), Q-KD (diastolic) 時間が，臨床的診 断に応用されらる。コ音を心電図, 指尖容積脈波, 力フ 圧などと同時記録し，健常者 50 名と各種疾患 11 種に ついて検討しすでに報告した．そのうち，大動脈弁閉鎖 不全, 大動脈弁狭窄 (AS), 大動脈弁狭窄兼閉鎖不全 では，旮れぞれ特徴ある所見を示した．今回は，AS 6 例, 老人で大動脈弁口に収縮期雑音を有する 21 例, 動 脈硬化症 12 例について比較検討した. 我々の正常做 (18〜33 才, 男子) は, Q-Ks が $0.314 \pm 0.024$ 秒, Q-KD は $0.222 \pm 0.017$ 秒, Q-Ks-D は $0.089 \pm 0.010$ 秒で変動は少なかった. AS では Q-Ks, Q-KD とも全 症例で高度の 延長を示し, その平均值は, Q-Ks は, $0.443 \pm 0.052$ 秒, Q-KD $0.261 \pm 0.026$ 秒であった。 老人で大動脈弁口に収縮期雑音を有する症例の Q-Ks は正常 7 例で, ほかは軽度の延長を示した。 Q-KD は 正常範囲のもの 3 例をのぞき, 大部分短縮を示し, AS のそれとは明らかに相違した。 その平均值は Q-Ks は $0.360 \pm 0.051$ 秒, Q-KD $0.185 \pm 0.018$ 秒であった。 病歴, 心音図, 胸部 X-P, 心電図, 血圧などとの比較検 討を行って，これらの方法では AS と鑑別のむずかしい 症例にも，Q-K 時間は有用であると判定しえた。また 老人で大動脈弁口に収縮期雑音を有する症例と動脈硬化 症の Q-K time は, Q-Ks, Q-Kn, ともに非常に似た 傾向を示した. 以上から老人の大動脈弁口に収縮期雑音 を有する症例（前者）と，ない例は収縮期雑音の有無で 著しく hemodynamics に差がないことを示するのと考 えられ，老人の診断上重要な所見と考えた．前者と AS 
との鑑別に，この方法が患者に苦痛を与えることなく， 日常きわめて簡単に実施でき, 単なる脈波伝達時間だけ の問題ではなく，いままで得られなかった血行力学的情 報を与兄らるものと推定し, 臨床応用への再評価を行の た.

\section{5. 梨圧物侗に関する研究（第 5 報）}

ーメコリールに対する血管反応性について一 吉田 稔 金沢武道 盛 英機 目時弘文 寺田俊夫 川島せつ 米田豊次 大池弥三郎

(弘大 大池内科) 松井哲郎

（弘大 健康管理センター） 小野寺庚午

（黎明郷リハビリテーション病院）

高血圧者の血管反応性を追求するために, メコリール (Mecho) 筋注による血圧下降度ならびに 血圧下降時に 連続記録された指尖容積脈波を検討した，1）Mechoに 上る血圧下降度は, 境界域高血圧群および高血圧群にお いては加令とともに大きくなるが, 対照の正常血圧群に おいては，その傾向は明らかではない．また中年拉よび 老年に沶いてては正常血圧群, 境界群, 高血圧群の順に大 きくなるが，若年においては，その傾向は明らかではな い２）脈波上よりみた Mechoによる血管拡張度合は， 高血圧群においても加令とともに小さくなるが, 正常血 圧群ほどには著明ではない。また若年および中年におい ては正常血圧群, 境界群, 高血圧群の順に小さくなる。 しかし老年においては血圧の高低にかかわらず，一様に， 若年および中年の正常血圧群に比べて，小さい，3）

Mecho による交感神経反応型については, 各血圧群の いずれにおいても加令とともに，低反応型を示すものが 多くなる．また若年，中年，老年のいずれにおいても， 正常血压群, 境界群, 高血压群の順に低反応型を示すも のが多くなる．結語：高血圧者においては正常血圧者に 比べて，Mecho による血管拡張の度合が小さいが，若 年者をのぞいては，血圧下降度は一般に大きい。このこ とは，高血圧者においては，その血管内腔が狭小化した 状態にあることを示す．またこのことは加令という因子 にも影響されているが，それよりも一層強く血圧という 因子に影響されている，また交感神経機能は，加令とと もに低下寸るが，これに高血圧という因子が加れると， この機能低下はさらに助長される。交感神経の機能六進 があって血管が機能的に狭小となっているときは，Me-
8 巻 4 号 $(1971: 7)$

cho 筋注によって血管は一次的に拡張し，その後の rebound によって二次的に血管の収縮が起こり，血圧は 上昇するものである. しかし交感神経の機能低下があり， しかも血管の器質的変化によって血管が狭小となってい るときは，Mecho 筋注によっても血管は，その器質的 変化のゆえに，十分には㧒張しがたく，また rebound に上る血圧の上昇は，その交感神経機能低下のゆえに起 こりがたいことになる。したがって，我々の観察した高 血圧者においては血管の器質的狭小が存在するものと考 えられる.

\section{6. フトトウ糖負荷前後における心血行動態について} 対馬信子 三宅直樹 岩本光存欣

工藤 守 平山亮夫 佐藤竜雄 (斗南病院内科)

健者 7 名 (27〜64才, 平均 44 才, 男 3 , 女 4 名) と糖尿病者 10 名 (36 63 才, 平均 50 才, 男 5 , 女 5 名）にブドウ糖 $100 \mathrm{~g}$ 経口，負荷した場合の心血行動 態の変動を心尖拍動図を中心に分析した。心尖拍動図は Benchimol の方法に従い記録し, 頸動脈波，心音図, 第II 肢誘導心電図と同時記録した。なお心筋収縮力を示

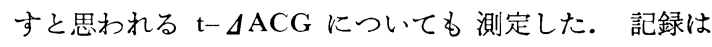
空腹時とブドウ糖負荷 1 時間後の 2 度行い, 同時に血糖, 血清総コレステロール值, 血清カリウム值を全例で検査 し, 健者 4 例と糖尿病者 10 例で Free fatty acid (FFA) をDuncan 法で測定した。

健者群ではブドウ糖負荷前後における心拍数変動が明 らかでないに対し，糖尿病群でブドウ糖後著明な心拍数 増加をきたするのがみられる．収維期の駆出時間を示す ejection component についてみると，健者群ではブド ウ糖投与に上る影響が明らかでないのに対し，糖尿病者 群では ejection component の短縮する例が 10 例中 7 例占める. 次に心䈈収縮力を示す $\mathrm{t}-\Delta \mathrm{ACG}$ は健者群で はブドウ糖負荷により 7 例中 6 例で $\mathrm{t}-\Delta \mathrm{ACG}$ の短縮, すなわち心䈈収縮力の堌強を認めるに対し, 糖尿病群で は一定の俱后を認めない。糖尿病群で t- $\Delta \mathrm{ACG}$ の変化 率がプラス，すなわち心筋収縮力減弱の方向に向か 5 む のでは Free fatty acid の変動が異常でブドウ糖負荷に よっても FFA 減少率が少ないか逆に增加するものが多 く, t- $\Delta$ ACG が短縮すなれち心䈈収縮力が㙕強する例 では FFA 減少が正常に認められる，今匜の成績は前腕 静脈血中の FFA 変動であり,これからたたをに心筋内 FFA 代謝を論ずるのはやや透確性を欠くと考えられる 
が，FFA 変動が心筋収縮能になんらかの影響を及ぼし ていることが推論される。

問：金沢武道（弘前大 大池内科）1）糖尿病患 者に $100 \mathrm{~g}$ GTT を行 5 と, 1 時間後，2 時間後では血 圧が変動する，すなわち上昇する群，変化しない群，下 降する群とまちまちであるが，ご発表のデータとこのよ らな血圧変動と関連があるようにも考学られるので，ご 検討しておったら，ご教示ください。

2）血圧レベルとの関係もご教示ください，

答：対馬信子 1) ブドウ糖負荷前後における血圧変 動については向後検討をすすめたい。

2）健者群では厳密に高血圧, 冠動脈疾患, 肝, 腎疾 患について除外してあるが, 糖尿病者群については高血 圧症，冠動脈硬化症なぞも含んでいるのて，例数を增す とともに詳細に分析をすすめている。

\section{7. 閉塞性動脈硬化症に関する研究（続報）}

—Xenon-133 クリアランス法に上る前脛骨筋の 血流測定とその臨床評佂一

原美利行 礒兼則子 本田由美子 島本多喜雄 (東医歯大 第 3 内科)

閉塞性動脈硬化症の下肢血流動態を把握するために Xeron-133を用いて Lassen の方法に徒って下肢の前 脛骨筋血流量を測定し，合わせて指尖容積脈波および血 管撮影所見との対比を試みた結果について報告した。

対象は閉塞性動脈硬化症 25 例で，コントロール例と しては健常例 4 例を含み，下肢の動脈拍動が正常で，脈 波所見も正常な例 10 例を用いた．測定方法は患者を仰 臥位にし，15 分以上安静に保たせたのちに，Xenon133 減菌生食液（約 $50 \mu \mathrm{c}$ の放射能を有する）を前脛 骨筋内に注射し, 注射部位の放射能を日本無線医理学研 究所の RI 動態機能検查装置了ロ力 PSM-1207を継時 的に 10 分間連続記録を行い，その消失曲線を描いて， Lassen の方法に従って血流量を算出した.

結果：閉塞性動脈硬化症で趾端にチアノーゼ，潰瘍の ない症例 20 例 36 肢の前脛骨筋血流量は $0.1 \sim 3.2 \mathrm{cc} /$ $100 \mathrm{~g} / \mathrm{min}$ (平均 $1.20 \pm 0.15 \mathrm{cc}$ ) で, 非血管閉塞例の血 流量 $0.5 \sim 5.2 \mathrm{cc} / 100 \mathrm{~g} / \mathrm{min}$ (平均 $1.9 \pm 0.26 \mathrm{cc}$ ) に比較 して有意 $(p<0.01)$ の低下をみた．閉塞性動脈硬化症で 趾端にチアノ一ゼ，潰瘍を有する 8 肢では，筋血流量は さらに低下しており，0.2 1.2 cc/100 g/min（平均 0.78 $\pm 0.11)$ を示し 8 肢中 6 肢は $1.0 \mathrm{cc}$ 以下の值を示した. 以上の上5に一般的に閉塞性動脈硬化肢の前脛骨筋血
流量は非血管閉塞肢に比較して低值をとる傾向にはある が，症例によっては䐐窝動脈，足背動脈がまったくふれ ず，趾尖の容積脈波所見が高度に悪化している症例でも， 前脛骨動脈血流量が正常平均を上回る症例もみられた。 このような症例では血管撮影により下腿上部の副血行路 が非常によく発達しており, 前脛骨筋血流が十分に保た れているとい5知見が得られた。

本法による筋血流量の測定は操作が簡便で副作用なく， 反復して試みることができるので閉塞性動脈硬化肢の下 肢循環とくにその局所筋血流動態を把握するのによい方 法であると思われた.

\section{8. 寒冷昇圧試験と脈波の变動よりみた老年者の 予後}

飯島紘栄 新 城之介 吉村正治 本田信義 漆山和夫 設楽悦朗 福原 清 加藤剛志 正田哲一 比企秀男 丸木多恵子 武田守正 （日医大 第 2 内科）

前後 6 力年にわたって, 主として老年者高血圧に寒冷 昇圧試験を行い，その前後の加圧脈波を記録し同時に心 電図, 眼底検査などの臨床検査を行い, 脳血管障害と心 疾患（高血圧性心疾患拉よび虚血性心疾患）の発生頻度 について検討した．対象は栃木県田沼町地区在住のもの で, 平均年令 71 才, 男子 25 例, 女子 42 例, 計 67 例. 初回検査は昭和 38 年 5 月, 2 回目は昭和 44 年 5 月に行った.

収綰期圧, 抎張期圧とも血圧の上昇とともに, 疾患の 発生頻度は増加した。寒冷昇圧試験について昇圧差 20 $\mathrm{mmHg}$ 未満の Hyporeactor の出現頻度は, 初回 39.3 \%であったが 6 年後には $78.6 \%$ と增加し, 疾患の発生 頻度もHyporeactor でやや高率を示す。眼底検査所見 では，例数の少ないI群，IV群をのぞき群でそれぞれ の疾患の発生頻度は高い。また高コレステロール群で高 率である。

追跡調査可能であった症例 28 例中, 指尖容積脈波の elasticity index 值 0.6 未満のものの発現頻度は 39.2 \%であったものが， 6 年後， $92.7 \%$ と著明に増加してい る. 各疾患の発生頻度についても EI 值 0.6 以上の群 で 40.9\% であるのに比し， EI 值 0.6 未満の群では $62.9 \%$ と高率であった，加圧脈波による 平均 elasticity index 值 0.6 以上の群で, 脳血管障害あるいは心疾患 のいずれかの発生頻度は $42.8 \%$ であるのに対し，平均 EI 值 0.6 未満の群で $73.3 \%$ と非常に高率であり, こ 
とに脳血管障害例では前者の群で 7.5\%であったのに比 乙後者の群では $40.0 \%$ とその傾向が強かった。

問：吉田 稔（弘大 大池内科）我々は,メコリ 一ルによる血圧下降時に指尖容積脈波を連続記録し，そ の際の, dicrotic index の変化をみてみると, 老年群, 高血圧群ではその変化が若年群，正常血圧群に比し小さ い.すなわちメコリールに対する血管自体の感受性が小 さいといら結果を得ている. 先生は寒冷昇圧試験，指尖 容積脈波などで老年者の予後を検討なさっておられたが， 寒冷昇圧試験前後における脈波上の EI 值, DI 值の変 化は，高血圧，老年ではどのような結果であったか.

答：設楽悦朗 寒冷昇圧試験前後の elasticity index の変化の傾向は寒冷刺激直後で低下し，時間の経過とと もに上昇する傾向にあった。したがって dicrotic index は逆の相関にあった。また 6 年間の期間をおいてからの 各症例の EI 值 DI 值の変動はとくに認められなかっ たように思われる。

\section{9. 超音波ドプラー法による末梢循環の研究}

一とくに老人の入浴時に打ける末梢循環について一 小林幸雄 葛谷文男 吉峯 德 脇田 保 北川道弘 古村憲資 前田周造 山田弘三 (名大 内科第 3 講座)

$\mathrm{NEC}$ 製方向指示型超音波血流計扣よびリオン製サウ ンドスヘククログラフを用いて老人とくに兴卒中患者の 入浴時の末梢循環について検討した。すなわち入浴前に 扣ける上腕動脈での逆流成分を含む血流パターンと入浴 中に打けるそれとを比較した，温度の影響を考慮して入 浴前の測定時には皮膚面と transducer との間に打く流 動パラフィンを加温し入浴時の温度と同じ条件にした。 若年者 4 名と片麻痺を有する 38 才より 80 才までの患者 16 名について測定した。結果，入浴による血流増大の 効果は明らかである．とくに正常方向流の増大は入浴直 後より認められるが末梢抵抗の減少を暗示していると思 われる逆流方向成分の減少ないし消失は，若年者打よび 片麻痺患者でも若年者では明らかであるが，高年令にな るにつれて減少率も少なく，減少するのに時間もかかる ように思われる. また正常方向成分の増加率のほうが逆 流方向成分の減少率より多く, 入浴による血流量の増大 は末梢抵抗の減少のみではないように思われる。な拈 圧については入浴開始 1 分後には上昇するものが多く, 入浴 5 分後では低下しているものが多い上うであった。
110. 動脈硬化症の研究（第 26 報）

一脈波速度による家兔大動脈壁硬化度の基礎的研究 (その 2 ) -

桜井 昇 高橋忠夫 吉村正蔵

須階二朗 岡村哲夫 林 哲郎

白川幹郎 大塚文輝 青木一雄 三川武彦

(慈医大 第 1 内科)

長谷川元治 木下重博 柿沼光代

（慈医大 付属西研究室）

林知己夫 駒沢 勉

（文部省統計数理研究所）

実験的動脈硬化家鬼を作製し，大動脈脈波速度 (Pwv) を計測（局麻下家兔左頸動脈波，左股動脈波，心音，右総 腸骨動脈最小内压 $(\mathrm{P})$ を同時記録し，心II 音前成分頸動 脈切痕間 (tc), 两脈波立ち上り差 ( $\mathrm{t}$ ), 動脈実長 (D) より $\mathrm{Pwv}=[\mathrm{D} / \mathrm{t}+\mathrm{tc}] \mathrm{p}$ となる) さらに摘出後の大動脈につい て, 形態組織学的諸量との対比を行った．対象は無負荷 群 7 羽，負荷群 23 羽の家兔で，コレステロール経口投 与，エピネフリン筋注， $\mathrm{N}_{2}$ ガス吸入の単独または併用負 荷を用いた．PWv計測後大動脈を摘出，1％ホルマリン にて固定，内膜アテローム点計量，内腔狭窄度扎よで弾 性線維粗密度の算出に用いた. 30 羽の刘象を組織学的に 検鏡し，無負荷群（A 群）主として内膜に病変が目立ち， 中膜に変化のないB群，内膜に変化をみず，中膜弾性線 維の獀せが目立ち，中膜の石灭化または壊死巣のあるD 群および $\mathrm{B}, \mathrm{D}$ 群の混合の様相を示す C 群の四つの群 に分類したＰPwv に差をきたす因子はアテローム変性， 内腔狭窄度および弾性線維粗密度が関与する。Pwv と 弾性線維粗密度との関係は指数関数的な減少を示し, 两 者は逆相関にあることを示唆している。またPuvは， $\mathrm{B}$ 群 (内膜型)， $\mathrm{C}$ 群 (混合型)， D群 (中膜型) の順に 高值を示し，血管弾性の減少に中膜因子がより重要な役 割を果たしていると考える. 実験的大動脈硬化家兔につ いて, 内膜型，混合型，中膜型 3 種の異なった形の動脈 硬化を作製しえたことに大きな意義があると考える。

111. 老年者における大動脈破裂の臨床病理学的研究 平岡啓佑 杉浦昌也 飲塚楯夫 上野邦弘 嶋田裕之

（都養育院付属病院 内科）

症例 : 最近 4 年間の連続剖検 800 例中にみられた大動 脈瘤の破裂 ( $\mathrm{A}$ 群) 4, 大動脈瘤以外の破裂（B 群） 4 の計 8 例. 性男 3 , 女 5 . 年令 $67 \sim 86$ 才平均 77 才. 方 


\section{一 般}

法: 肉眼的に観察し, 弓部, 胸部, 腹部大動脈から各 2 カ所と破裂部位を切り出し，H-E， EvG 染色し検鏡し た. 成績: 全例高血圧. 梅毒血清反応, 陽性 1 , 陰性 6 , 不明 1. 胸部X線検查, 動脈瘤 4 , 幅拡大 2 , 石灰化 4 . 破裂の誘因, 洗濯, 洗面, 排便, 入浴, 床上げなどの体 動各 1, 転落 (ベッド, 二階) 2 , 不明 1 . 症状, 胸部 不快感 2 , 悪感 2 , 不明 4 。死亡までの時間, 瞬間 3 , $4^{\circ} 30^{\prime}$ ないし 10 時間 5 . 病理学的所見: (A群) 霟状 3 , 紛錘状 1 . 破裂大動脈痹最大径 $5 \sim 12 \mathrm{~cm}$. 破裂大動脈 痹, 上行 1 , 弓部 2 , 胸部 1. 裂口, $1 \sim 2 \mathrm{~cm}$. 出血部

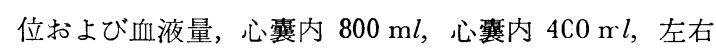

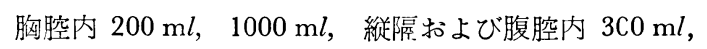
$500 \mathrm{~m} l$. Gore の指数, 27, 35, 55, 45. 破裂部組織所 見, 全例アテローム, 弾性線維の断裂や消失による硬化 性病変が成因.（B 群）破裂部位, 起始部 3 (大動脈弁 右尖の上 2 4 cm), 弓部 1 . 裂口 $2 \sim 4 \mathrm{~cm}$. 出血部位 おょび血液量, 心囊内 $600 \mathrm{~m} l$, 心囊内 $500 \mathrm{~m} l$, 心襄内 $430 \mathrm{ml}$, 左胸腔 $150 \mathrm{~m} /$. Gore の指数, 45, 45, 28, 9 . 組織学的所見：4例とも異なり，それぞれ(1)石灰化を伴 ラアテローム斑菲薄部。(2)梅毒性中膜炎. (8)広範囲びま ん性の中膜筋細胞の減少と弾性線維の細少化と乱れあり. 断端の一部に中膜の急性壊死を認めた。(4)ほほ健常大動 脈であった．総括：老年者の大動脈の破裂の頻度は $1 \%$ で老年者急死の一大要因を占める.大動脈瘤以外の破裂 には，破裂部の病変がそれぞれ異なるが，部位が起始部 から弓部の兜椎付着部にあり，とくに大動脈弁右尖上 $4 \mathrm{~cm}$ 以内に多いことは血行動態的因子の強い関与が示唆 される.

翼問：村松 睦（榛名荘病院）大動脈瘤の rupture の報告で興味深いことですが，なにか生前の clinical signs たとえば胸部 X-P や Fhysical signs で異常所見 がつかめなかったか，打教えください．

答: 平岡㤵佑 大動脈破裂を前もって予知できるもの がなにかあるかということだが，高血圧以外に特街的な 疾患とか, 症状とかはなかった。

\section{2. 本態性高血圧症の腹部大動脈像について}

小野江為久 石瀬昌三 原 重樹 舟津敏朗 竹内伸夫 金 武雄 土屋雅之 平丸義武

竹越 袈 村上暎二 村上元孝

(金沢大 第 2 内科)

本態性高血圧症 58 例の腹部大動脈写について, 年代 別に分けて比較検討した. 大動脈の蛇行や辺縁の不整,
演題

8: 189

腎動胍の蛇行や辺縁の不整いずれも高年者に多かった. しかしながら脾動脈の蛇行は大動脈の蛇行のない20才 代でもすでに半数以上にみられた。腎動脈では左右の太 さの違うものが多く，右政動脈がやき太かった．大動脈 と腎動脈とのなす夾角は左腎の大きいものが多かった。 過剩動脈の頻度は $25.5 \%$ で，これまでに発表されてい るものとほほ一致していた。これらの所見は加令とかな り密接な関係を有することが知られたが, 今後の問題と して血圧との関係や，機能的な点に関しても検索を行う 予定である。

筮問：荻野耕一（京大 第 3 内科）腎動脈分岐角, 腎動脈太さ/大動脈太さ比と高血圧ないし腎血行動態と の相関関係はあったか.

答：小野江為久 大動脈の太さの割に腎動脈が細いる の, および大動脈と腎動脈とのなす夾角が極度に大なも のでは症例は少なかったが血圧がほかに比して高い㽖象 を受けている。

腎血行動態については測定してあるが今回は発表しな かった.

\section{3. $\mathrm{X}$ 線写真上の大動脈石灰化像とその意義}

藤井 潤 矢崎義雄

(朝日生命成人病研究所)

$\mathrm{X}$ 線写真上みられる大動脈石灰化の臨床的意義を明ら かにするため, 40 才以上の 930 例を対象とし, 胸部正 面像打よび腹部側面像より大動脈石灰化を検討した。

1）大動脈弓部石灰化の頻度は 40 代，50代，60 代 のいずれの年代でも男より女が，大動脈腹部の石灰化は いずれの年代でも女より男が多い。

2）高血圧，糖尿病のない例でも大動脈石灰化の頻度 は年代とともに増加し，60 代男では35\%に達する. 高 血圧例, 糖尿病例では 50 代ですでに，それぞれ $48 \%$ ， $42 \%$ に達しており，これらの疾患では大動脈石灰化が 10 年早く起こることを示している.

3）大動脈弓部石灰化例では, 高血圧や糖尿病の頻度 は石灰化のない例とかわらないが，大動脈腹部石灰例で は高血圧や糖尿病の頻度が有意に多い。

留問：金沢武道（弘大 大池内科） 1）大動脈の石 灰化像が認められても normotension のことが以外と 多く，とくに老年者に目立つ. しかし Anamnese を聞 くと, 以前に高血圧であったことがあるという例が以外 に多くある. 石灭化を一応不可逆的变化とすると variable な血圧との関連を論ずる場合，不合理な面がでるが， 
先生のところではどのように処理しておられるか.

2）大動脈弓部の石灰化は加令とともに增加はしてい るが，その増加率は血圧などを考虑に入れると必らずし も加令と関連が深いといいきれないように思われるが， その点どのように怙考旮か。

答：藤井 潤 1) 血圧は初診時の血圧值を採用した。

2）加令とともに増加するとい5のは, 高血圧糖尿病 がなくとも 40 才代では数\%で 60 才になると $35 \%$ に 達しており，明らかに有意の差がある。

3）（座長の 111 に対する質問に対する追加）

東大第 3 内科で Aneurysma がなく，上行大動脈に亀 裂ができて破裂した例を経験した。

追加 - 問 : 長谷川元治(慈大 第 1 内科) 1) Aortic calcification について X 線撮影の条件は?

剖検例では，X-P よりも calcification は上回る.

2) Essential hypertension に扮ける aortaは, radius, thickness の増加はあるが calcification とは必ずし も一致しない。

答: 藤井 潤 大動脈石灰化には特別の条件でX線を そってはいない.

\section{4. 老年者胸部単純側面写真よりみた大動脈陰影 の臨床的病理学的研究（第 3 報）}

蘇 進一 村松 睦 岸本篤郎

（漛名荘病院） 奥平雅彦

(東大 病理)

目的：大動脈動脈硬化症の X線学的評価の一方法とし $\tau$, 我々は胸部単純 $\mathrm{X}$ 線側面像の大動脈影の明瞭度（I 〜IV群）より臨床病理学的検討を行い報告してきた。

方法: 今回は本院の 5 年間 150 剖検例中, 本側面写 真を有する 63 例をもとにして病理所見について比較し た.このうち 14 例は条件の不適合により除外した。症 例の 3 分の 2 は 70 才以上が占め, 我々の分類による I 群とIV群を呈したものは皆無で, 過半数が III 群付近の 像を呈した。主疾患としては循環系疾患が $72 \%$ ，覀性 腫瑒が $15 \%$ である。これらのうちもっとも典型的なX 線像を呈した 19 例（II 群 4 例, III群 11 例，III 〜 IV群 4 例）につき弓部と胸部大動脈のそれぞれを超軟 $\mathrm{X}$ 線に より石灰化巣を, 視診と触診により肥厚部を調べ spotting method により百分率を求めた。 また一律第 1 と 第 2 肋間動脈間で大動脈片を採り内膜肥厚度を micrometer で測定し，さらにその組織学的検査を行った. ま

8 巻 4 号 $(1971: 7)$

た検索対象の多くにみられた高血圧症との関連の一端を みるため全例の心重量と大動脈幅について計測した。

結果：硬化性病変の百分率を求めた 19 例についてを ず両端に位する II 群とIII〜IV 群について比べると II 群弓 部で 12.5 40\%，胸部で 20.4 28.7\%，III～IV 群弓部 で 69.6〜98.3\%，胸部は 69.6９3.1\%とその硬化重症 度がまったく群別に比例することが認められた。しかし III群（11 例）は硬化強弱の各段階が含まれており（弓 部 $0.5 \sim 88.4 \%$ ，胸部 0.3〜88.9\%)，したがって単に $\mathrm{X}$ 線上の明瞭度からは硬化所見とはみなしえない，しか 乙主疾患が動脈硬化性疾患であるものについて調べると 各群別と重症度の相関を認めうる．内膜の厚度も III, III 〜IV群では増す傾向があり，かつ組織学的に石灰砂や石 灰板を含むのが多かった。重量と大動脈幅はほとんど 群別との関連を見出せなかった。

断察: 胸部単純側面像よりみた大動脈影の形成の一因 として大動脈硬化症が関係し，その明膫度は主疾患を十 分考虑すれば大動脈硬化度の重症度の推定の一方法とし て意義あるものと考える。

\section{5. 心・脳放射図のアナロク解析による心・脳血行 動態の臨床的研究}

㷋野耕一 平川顕名 岩井信之 高安正夫 (京大 第 3 内科)

目的：脳血行動態を彷来の方法より簡便に分析しかつ 心機能と脳循環との相関を追究するため体外計測法とし ての心・脳放射図のアナログ計算機によるミシュレーシ ョン解析法での量的分析を工夫し, 昨年度本学会・日循 学会に報告した，今回はその臨床応用と，疾患別または 眼底所見別の脳循環諸量の比殡，脳循環と心機能との相 関などにつき報告する。

方法：心・脳放射図の記録法打よび，そのアナログ解 析法の原則については昨年度の報告した通りである。

(第 9 回日本 $M E$ 学会予稿集 116 頁捄よび第 34 回 日循総会予稿集）これにより左右心・肺・体循環量を計 測し，この心放射図の分析を基醍に，脳循環諸量を計測 する。

成績：1）方法の吟味 本法は心・脳血行動態の同時 解析とともに両者の相関を検討できる特徴を有する反面, 心・脳のコリメーションに注意を要する。部は欠ける ことなく検出すること, 脳は外頸動脈域を可及的に含ま ないことが必要である，2）脳血流量/心拍出量比は心機 能 (心拍出量, 左心一回拍出量/左心容比) 飞逆比例す 
ることは昨年報告したことを確認した，3）正常平均值 は脳血流量 (CBF) は $63.2 \pm 13.3 \mathrm{cc} / \mathrm{min} / 1009$, 平均通 過時間 (MTc) は 7.77士1.22 sec であったが，脳血管 障害患者・高血圧症群では正常群に比し有意に低值であ った. 4) $\mathrm{CBF} 40 \mathrm{cc} / \mathrm{min} / 100 \mathrm{gm}$ 以下を Low CBF 型 (L 型), $\mathrm{MT}_{\mathrm{C}} 9.5 \mathrm{sec}$ 以上を Delay 型 (D 型), この 両者の合併を DL 型, この值より 正常側にあるものを $\mathrm{N}$ 型とすると, 脳血管障害では $\mathrm{DL} \cdot \mathrm{D}$ 型が $2 / 3$ に, 高血圧症では $1 / 2$ に見出された，5）ことに新鮮血栓， 重篤な神経症状を有する患者は主に DL 型であった。 その 1 例を例示した. 6) 眼底所見 $\mathrm{KW} \mathrm{II} \mathrm{または} \mathrm{S}_{2}$ 以 上と以下の二群間には $\mathrm{CBF}, \mathrm{MTc}$ ともに有意の差がみ られた。

結語 : 本法は患者に対する負担がきわめて軽く, 反復 実施可能で, 脳循環障害のスクリーニング・経過観察に 容易に実施可能な有用な脳循環検査法である.

\section{6. 瞏における腺境界の経年的推移について}

-Atrophic pattern と加令一

木村 健（東大 第 3 内科）

小西建吉 (国病東一・消化器科)

金子 仁（国病東一.病理）

從来, 萎縮性胃炎は高年者に打いて, 高頻度に認めら れるとされてきた. しかしながら過去においては，萎縮 性胃炎を拡がりの観点から追求することは, 方法論の制 約から非常に困難であっだ.しかし近年, 内視鏡の進歩 によりこれらの困難は克服され, 萎縮性胃炎の動態を加 令との関係において, Magen 全体から dynamic に分析 しうるようになった。

現在, 内視鏡で atrophic border はほとんどの症例で 観察可能である.この atrophic border は組織学的に, 正常と萎縮性胃炎領域との境界であることが詳細な組 織学的検索で証明された. したがって，この atrophic border を観察することにより，Magen における萎縮性 胃炎の広がりを識ることができる。この atrophic border の存在位置により, Magen をいくつかの patternに 分類し,この atrophic pattern と年令との相関を検討 することにより, 萎縮性胃炎を加令現象の観点から追求 した. Atrophic pattern は萎縮性胃炎の平面的な広がり を考慮したもので，その広がりの多寡により C-1，C-2， C-3 および O-1， O-2， O-3 の 6 型に分類した. 男 961 例（女 487）において各 atrophic pattern の平均 年令をみると，C-1: 27.3 (28.0)，C-2: 31.4 (33.3)，
C-3 : 35.9 (40.1), O-1: 42.9 (47.9), O-2: 50.0 (55.5), O-3:59.0 (65.3) であって, 萎縮性胃炎は加 令とともに広がり，しかも各 atrophic pattern の平均 年令には, 統計学的に高度の優位差が認めにれる. 同時 に性差も傾向としてうかがわれるのである.

このように萎繀性胃炎の広がりと加令には密接な関連 性が存在しており，これを胃における normal aging process とみなしうるのである.

さらに，萎縮性胃炎を加令現象の観点からとらえた場 合，必然的に胃年令（stomach age）なる概念の導入が 必要となり，かつ，それが可能なのであって，萎縮性胃 炎の診断に際しては，個体年令と胃年令とを求め，この 両者に gap がある場合にのみ atrophic gastritis なる 臨床的診断をくだすのが妥当であると考えている。

問: 高瀬靖広（東女医大 消化器病七ンタ一）小 彎線上の atrophic border の広がりと, 大彎側とくに出 門洞大彎の広がりとに関係があるか。

答：木村 健 萎縮性胃炎の進展に関し，小彎ではそ の進展の speed が速く，一方大彎では遅い.しかしな がら，大彎線においても萎縮性胃炎は加令とともに進展 していることは事実である。

問 : 丸山正隆 (東女医大 消化器病センタ一) Atrophy の広がりについては非常に美しい結果をおみせ いただいたが， atrophy の程度については加令による变 化があるのか.

答：木村 健 萎縮性胃炎は, expansion（範囲）と severity (程度) に規制されながら立体的に進展しており， 両因子とも加令と密接な相関を示している.

ある局所における萎縮性胃炎の程度を年令との関係に おいて検討すると, 若年者では軽く, 加令とともに強く なっていく傾向が明らかに認められている.

\section{7. 高血压性脳出血に伴う急性罱十二指腸病变に 関する臨床的研究（第 $\mathbf{1}$ 報）}

—とくに胃液分泌を中心として— 山口一彦 金谷春之 大沢謙一 小野寺英樹 小林貞夫 田村健一

(岩手医大 第 2 外科)

高血圧性脳出血剖検 75 例飞おいて確かめえた胃十二 指腸病変は, 外側型 $58.8 \%$, 混合型 $85.2 \%$, 橋出血お

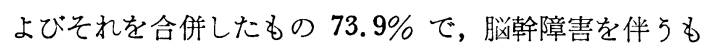
のに多い傾向にある。これら症例の一部拉よび生存例の 早朝空腹時無賦活遊離塩酸度は, 胃十二指晹病変の有無 
にかかわらず発作後 20 日以内で高値を示す傾向にある. しかし胃十二指腸病変を有するものでは，31 日以上た っても高值を示す傾向にある．脸病巣と胃液の関係では， 外側型・混合型のいかんにかかわらず, 発作早期から 20 日ぐらいまで遊離塩酸度は高值を示すものが多いまなた 急性潰瘍, 出血性糜爛などの病変の違いによって酸度の 消長に特異的なものはない。また副腎皮質機能として尿 中 17-KS, 17-OHCS の消長をみたが, 胃十二指腸病変 の有無と特異的な関係はみられない。組織学的に粘膜被 蓋細胞を有する下層の粘膜組織において粘膜下静脈, 粘 膜毛細血管の拡張, 出血, 出血巣の融合像など特徵的な 像がみられることで，これら粘膜の血管性病変が急性胃 十二指晹病变形成の初期像と考兄られる. 脳内血腫注入 に伴 5 犬胃の胃血流・胃運動・胃液酸度の相関を同時多 相記録により検討すると，血腫注入とともに胃運動元進， 胃壁血流の増加, 遅れて $\mathrm{pH}$ の低下などがみられる. し たがって, 高血圧性脳出血に伴 5 急性胃十二指腸病变の 発生因子として，胃壁血流の障害に伴う胃粘膜血管の病 变が主因で, 胃液はその急性病変の進展過程の中で二義 的に関与してくるものと思われる.

問：市岡匹象（東女医大 消化器病七ンター）高 血圧性脳出血に伴った急性潰瘍の発生部位, 性状は通常 みられる同年令層の潰瘍と比べて特徵があるか.

答: 大沢謙一 高血圧性脳出血に伴う急性病変は, 粘 膜出血, 出血性糜爛などは昌の全般に及んで扣り, 急性 潰瘍になると胃道部を中心に発生してくる.したがって その傾向としては, 慢性消化性潰瘍の発生部位と類似し てくる傾向にある.

追加：並木正義（北大 第 3 内科）脳卒中に伴う胃 の潰瘍性变化の発生部位について我々が検討した結果で は，胃体部後壁に多いという傾向をみておる。

\section{8. 加令之腸上皮化生胃炎（続報）}

一とくに十二点生検法を中心として—— 高瀬靖広 市岡四象 遠藤光夫 榊原 宣 鈴木博孝 鈴木 茂 横山 泉 山下克子 野村修三 中村光司 山田和毅 竹本忠良 （東女医大 消化器病センター）

我々は第 11 回本学会総会において, 腸上皮化生性胃 炎における腸上皮化生の出現率を原発性慢性胃炎切除例, 十二点生検例から検討し報告した. 今回は十二点生検法 の小彎線上の 4 力所，すなわち，胃体上部・胃体中部・
8 巻 4 号 $(1971: 7)$

胃体下部および幽門洞小彎を対象とし，腸上皮化生の細 胞成分を分析して腸上皮化生の機能の一端を追求した。 まず胃内各部位での萎縮性胃炎の程度と腸上皮化生の出 現率との関係を検索すると，60才以上の高年者と 59 才 以下の中年以下のグループとでは, 部位により若干の差 を認めるが，いずれも萎縮性胃炎が高度になるに従い， 腸上皮化生の出現率も増加する. そこで萎縮性胃炎の程 度と腸上皮化生の出現例数を, 前回報告したように腸上 皮化生の程度を I 度, II 度およびIII度に分け全部位でみ ると, 萎縮性胃炎の程度が増すにしたがって腸上皮化生 も高度になることを認め，とくに高度萎縮性胃炎では， ほとんど腸上皮化生を高度に伴っている．そこで腺組織 のほとんどみられない高度萎縮性胃炎で腸上皮化生を $61 \%$ 以上に伴う症例を中心に, 60 才以上と 59 才以下 のグループとの腸上皮化生の構成細胞の量的関係を検索 した. その結果, 検索 51 例中 Paneth 細胞を認めるも のは 7 例でいずれる全腸上皮化生中に占める比率は $1 \%$ 以下で，ほとんど吸収上皮と杯細胞であった。そこで杯 細胞の全腸上皮化生に対する比率を求めると，高年者で は，杯細胞の占める比率が $20 \%$ 以下の場合は 19 例中 14 例 74\%，21\%３0\% では 5 例 26\%，31\% 以上は 認められなかった，中年以下では，杯細胞の占める比率 が 20\% 以下では，32 例中 19 例 59\%，21\% 30\% で は7 例 22\%，31\% 以上は6 例 19\% で高年者のほ5が 杯細胞の占める比率は少ない傾向にあった，以上，胃分 泌機能における腸上皮化生の占める位置, 個々の杯細胞 の分泌についても不明だが，高年者の腸上皮化生中の杯 細胞の占める比率が低いということは分泌機能低下の一 つの現われであろうと推察し報告した。

啠問：金子 仁（東一病理）腸上皮化生に関して杯 細胞や，パネート細胞はよくみるが，吸収上皮に関して は余り注意を払わなかったが，この吸収上皮に関してお 教えいただきたい。

1) Cuticula を有する細胞をいうのか.

2)この細胞はどのような意義を有するのか.

\section{9. 老年者胃潰疡の最近の傾向}

中川健一諸岡忠夫 河内秀希 上田則行 千秋孝夫 並木正義

(北大 第 3 内科)

老年者胃潰瘍については，種々の点において特徴があ る.これをかっての 10 年間と最近の 3 年間の傾向と比 較しながらのべた.

1958 年から 1962 年までの 5 年間に取り扱った全胃 
潰湯は 413 例で、これを $\mathrm{A}$ 群とし, 1963 年から 1967 年までの 5 年間の 568 例を B 群, 次いで 1968 年から 1970 年 10 月までの約 3 年間の 537 例を C 群とした。

老年者胃潰瘍を一応 60 才以上の胃潰湟とするとき, 60 才前に発病してそれが 60 才以上に持越された場合 と，60才代になって初発したものがあるわけだが，老 年者胃潰瘍の瀕度は，A群 $14.5 \%, \mathrm{~B}$ 群 $18.1 \%, \mathrm{C}$ 群 $19.7 \%$ と最近増加の傾向にあり，乙か子 60 才代初発 の頻度も大となっている.

胃潰瘍は年代のすすむにつれて, 胃体部に発生する頻 度が大となる傾向は, 昔からいわれてきたが， B 群と C 群とを比較してみると， $\mathrm{C}$ 群に打いてその傾向がより著 明となっている，ただ最近は各年代ともなぜか胃体部の 発生頻度が増加しつつある。このままいくと将来老年者 胃潰瘍が胃体部に好発するという特徵は薄れていくかも しれない。

老年者胃潰瘍に大きな潰瘍の頻度が高いことは知られ ていたが，この傾向は最近において一層目立ってきた。

老年者胃潰瘍の主訴としては，上腹部痛よりも胃部膨 満感，重圧感といったばくぜんとした症状のほうが多い が，ただ最近痛みを訴える頻度が昔より大となっている. 吐血，下血などの顕出血の頻度も最近はより高い．ただ これも各年代とも高くなっている.

胃潰瘍の再発の誘因として精神的過労, 身体的過労, 食生活の不適当をあげ，各年代別にみてみると，老年者 においても精神的過労が $32 \%$ にみられ，最近では誘因 の第一を占める．老年者胃潰瘍は從来からいわれている ような特徴を保ちながらも, 最近, 若年者潰瘍との類似 性を示しつつあるといえる。

120. 高令者胃溃场の初診時所見および経過につ いて

石原 晃 北野 宽 川添大士郎 都築実紀 郷治広達 吉田台美

(大同病院内科)

岡勇二 水野孝彦

(名大 第 1 内科)

我々は名大第 1 内科および関連病院において発見され 内科的に治痛または 6 力月上上経過を追求しえた胃潰瑒 458 例につき, 60 才以上の胃潰瘍 92 例と 60 才以下 の胃潰瘍 366 例の初診時所見および経過予後につき比較 検討し次の知見を得た。

1）高令者胃潰瘍は胃体部に多発し，60 才以下の症
例は胃角部に多発する傾向を認めた。

2） X線上ニッシエの大きさ拉よび梁さに関しては軽 微ではあるが高令者例において大きくて深い潰瘍が多い 傾向を認めた。

3）胃カメラ上潰瘍苔の性状は高令者例において黄白 色および污跲〜出血を示す例が多く, また潰瘍辺縁隆起 に関しても高令者例に著明な例が多く認められた．粘膜 譬の集中は両者間に差は認められなかった。

4) 内科的加療による胃潰演の経過をみると, 加療 1 力月後の治癒率は高令者例 $21.7 \%, 60$ 才以下の症例 23.5 $\%, 3$ 力月後の治瘺率は高令者例 $75.0 \%, 60$ 才以下の 症例 $73.2 \%, 6$ 力月後の治㾤率は高令者例 $82.6 \%, 60$ 才以下の症例 $85.5 \%$ で両者の間にほとんど差はなく高 令者例においてもよく治癒する傾向が認められた。

5） 2 年以上経過を観察しえた症例における胃潰瘍再 発頻度は高令者例 $41.5 \%, 60$ 才以下の症例 $52.6 \%$ で 両者ともに高率であった。

6）再発胃潰瘍の経過は高令者例において難治例が多 くなる傾向が認められた

\section{1. 高年者に初発した罢溃清の検討}

山城 守也 鈴木雄次郎 $<$ 外科 $>$

久保富美子 $<$ 内科 $>$

嶋田 裕之<病理 $>$

（東京都養育院付属病院）

高年者にみられる胃潰瘍には，高年になって初発する ものと, 若壮年時よりの遷延性難治性潰瘍, 死前期など にみられる急性びらん，急性潰瘍などが考えられる.

我々は今回 60 才以後に初発したと考えられる胃潰瘍 症例について報告する.

判定規準は, 潰瘍の存在が手術, 剖検, $\mathrm{X}$ 線その他の 検查で確認されたものの5ちから 60 才以後に初めて発 症したものを主たる対象にした.さらに 60 才以後に集 団検診などによって無症状で発見されたものも含めた.

これらの症例は手術例31例, 保存的治療例31例である. その年令, 性別分布は, 母集団としての養育院在院者の 年令, 性別構成とほぼ同比率を示しておりとくに胃潰瘍 症例に括いて差異は認められない。症状および合併症の 発現頻度では，若年者層のそれと此べ疼痛を訴えるもの は少なく，逆に吐血，下血をもって始まるものが多い.

予後に関しては, 手術例では疼痛を理由とするものの ほかに, 出血を理由とするものが多く, しかも出血例で はすべて救命しえている.しかしまた出血例ではしばし 